\title{
Salman Rushdie's Midnight's Children, The Play as TeXt and Performance: An InTroductory Note
}

\author{
D.C.R.A. GOONETILLEKE \\ Emeritus Professor University of Kelaniya, Sri Lanka \\ dcragoonetilleke@sltnet.lk \\ Received: 26-08-2014 \\ Accepted: 24-10-2014
}

Salman Rushdie himself wrote a screenplay for a proposed BBC adaptation of Midnight's Children. The project collapsed twice because first the Indian Government and then the Sri Lankan authorities gave in to Muslim objections and refused the BBC permission to locate the mini-series in these countries. Rushdie's five-episode, 290-minute television dramatization was published in 1999 - after its BBC production was finally abandoned. ${ }^{1}$ But the Royal Shakespeare Company was keen on a dramatization for the theatre by Rushdie with Tim Supple, with whom he had collaborated on the acclaimed stage version of Haroun and the Sea of Stories at the Royal National Theatre in 1999. The RSC originally requested a version of Alice in Wonderland, but Rushdie felt that there was no special reason why he should be the one doing that and showed the RSC the screenplay of Midnight's Children. This led to the adaptation for the theatre of Midnight's Children (2002) with Rushdie as author and co-adaptor, Simon Reade as co-adaptor and dramaturg, Tim Supple as co-adaptor and director.

Supple said: "We are not setting up to try to replicate the book on the stage, we will try to create something that is like a sibling to the book, and just as multi-layered" (Gibbons: 11). Rushdie's own stage experience, minimal though it was, probably was a useful guide. He was involved in student productions, acted briefly in the fringe theatre circuit after graduation, occupying a marginal position, and has confessed recently: "I always loved the theatre" ("Interview”, 2003: 12). His early professional experience in
\end{abstract}

\footnotetext{
${ }^{1}$ A new government gave permission for the film version to be shot in Sri Lanka, directed by Deepa Mehta. It was released in 2013.
} 
advertising may have come in handy. Advertising is a merciless discipline: it teaches the writer what is essential and how to manipulate his audience. A man who has written advertisements will know where the punch must occur. It is amazing that so much of the verve and width of suggestion in the novel (panoramic, non-linear, tragic-comic, encompassing history, religion and politics) and its ability to activate the reader's mind remains in the compressed and sharply edited version of the play, quarter of a million words contracted into three hours of theatre. Ultimately, this is only possible because Rushdie, who conceived the whole, is certain where the stress should fall in every phase of the novel and can cut with a sure and skilful hand. The galloping of Shivaji's statue, effective in the novel as suggesting Hindu militancy, is missing but the dialogue of the drama brings out the fissures sufficiently; predictably snakes, Dr. Schaepsteker's Institute and the Tubriwallah are deleted. The play makes racy reading and retains the best in the judgment of those familiar with the text, yet may have fared poorly in performance. The phantasmagoria in the Sundarbans with the temptresses, the charred skeletons, comes out forcefully, the journey through the jungle being inspired by Apocalypse Now almost intertextually (the Americans at war in Vietnam, the Pakistanis in Bangladesh). When the Emergency is taking place, Shiva (the name indicates his propensities since Shiva is the Destroyer in the Hindu Triad) wants to smash the Midnight's Children Conference and takes Saleem into an interrogation room. The disclosure of their identities is dramatically very effective:

Saleem: He's really me. I'm really him.

Fat Man: He doesn't know what he's saying.

Saleem: Born together. Same place, same time. Then ... a mistake.

Shiva is now interested - his face close to Saleem's.

Shiva: What's this nonsense? What mistake?

Saleem: The babies. You're really me. I'm really you.

Thin Man: Are you following this, Major?

Fat Man: It's some sort of fixation.

Shiva (enraged as it dawns on him): Bastard. Haramzada. ${ }^{2}$

\footnotetext{
${ }^{2}$ Adapted for the theatre by Rushdie et al., pp.111-12. All subsequent references to the adaptation are from this edition and the page numbers are incorporated in the text.
} 
The play departs from the novel at certain points. Since drama is required, more prominence is given to the Lila Sabarmati and Homi Catrack illegitimate affair; Lila has lines to speak and is not just a figure in the narrative. The Sabarmati killing, Amina's reaction and Hanif's death, are all splendidly theatrical; what is merely recorded in the novel gets forcefully foregrounded. In the novel the significance of the birth of Saleem and Shiva is discovered gradually, but in the play it is focused on at the beginning. The birth scene is repeated (40) and thus highlighted as a focal point. The switching of the tags of the babies is surreptitious and reported in the novel, but in the play it is foregrounded by being performed and witnessed by the multitudinous eyes of the audience. "The nice white bed" (1) on which Amina Sinai lies, and "the plain metal bed" (1) of Vanita offer a contrast and underline the class issue. Joe D'Costa's name suggests a Eurasian of Portuguese/Goan extraction, marginalized and powerless, unlike the Imperial English or the natives rooted in the soil for centuries. He is an orderly while Mary, his girl friend, is a nurse - at Doctor Narlikar's Nursing Home where the babies are born. Joe says:

We have to do it now, Mary. The real revolution. The rich must fall; then we'll have our freedom. (42)

Mary switches the tags of the babies and exposes her motivation:

I'm doing this for you, Joseph. Let the poor be rich, and the rich poor. (42)

There is more emphasis on the class struggle in the play (and in the 1999 The Screenplay of Midnight's Children) than in the novel. Robert Brustein argues: "Saleem and Shiva, the switched infants, are forced to represent the artificial division between the entire Muslim and Hindu nations" (Brustein). I think (like Joe D'Costa) they represent the division between the Haves and Have-nots. (The racial affiliations of Saleem and Shiva are complex.) The young Saleem expresses the ideals and aspirations for Midnight's Children:

What's all this? High-caste, low-caste - Hindu-Muslim - rich-poor - that's not for us! We can find a ... a new way. (79)

There is in the play a projection of a visual representation of India - with its contrasts and cleavages. The audience has time to focus on the screen; the more perceptive will see the 
significance (the less at least the multitudinous confusion), the difficulty of taking in India and seeing it whole - what Mrs Moore in A Passage to India faces from different scenes and their intimations as she leaves India is what Rushdie also conveys through the partial glimpses afforded by the perforated sheet in the novel and in the play. The play is spare and also stylized: there is hardly any scenery; the props are minimal; banners of fabric form a backdrop; a ladder suggests stairs; a few actors in uniform represent an army; characters come on and off the stage without plot motivation. The stage is dominated by a giant diagonally bisected movie screen. Throughout the play we see historical film, like that of Nehru announcing India's Independence, as well as film of the characters shot specifically for the play. The concurrent use of stage action and multimedia devices re-enacts the newness, the different levels and mixed genres of Rushdie's technique in the novel. The play is a work of art in its own right as well. It has zing and zest, yet it is not fully successful as theatre. Conflict and tension are the essence of drama. The play has plenty of conflict, but it is diffuse; it lacks a sense of intense, focal conflict. It is episodic - deliberately so. Rushdie has explained that the style the collaborators went was for "a cinematic effect, with a large number of very short scenes." (James). But the fact is the play is not sufficiently cohesive, being too diffuse and centrifugal. Saleem Sinai, the protagonist, does not hang together as a cohesive human character both in the novel and in the play, though by representing India he does exhibit the plight of the sub-continent in a human way. Shiva is stick figure. Padma is important as Saleem's Muse and the reader's/theatregoer's surrogate. She emerges vividly both in the novel and in the play as a full-bodied character, but she is the only such figure in the play.

The Royal Shakespeare Company brought its London production to the University of Michigan at Ann Arbor and, sponsored by Columbia University, to the Apollo Theatre in Harlem in March 2003. Together, the two universities paid more than \$2 million to the RSC to help commission the play. It is important to observe that the production was funded by universities, not publishers or theatre magnates. Indeed, Columbia University held a month-long "Midnight's Children" Humanities Festival around the same time. Both universities offered a large number of conversations, roundtables, panels, rehearsals 
and readings related to the play, all open to the public. The play was performed six times at Michigan and twelve times in New York. All these facts testify to the magnitude of the book, the author, and also to academic dictates.

However, the performance of the play in London and the US was considered a flop by critics, though the RSC claimed to be happy that the London version played to 75 percent capacity and, according to Rushdie, "audiences responded enthusiastically to the play" (James). The play has its intrinsic flaws, but the performance itself had its shortcomings. Robert Brustein, for instance, picks out weaknesses in the acting (the cast was mostly Anglo-Asian and Asian, a significant first for the usually Caucasian RSC, but they were not among the better players in the London theatre) and the

mostly damp theatrical squibs, signified by over-amplified explosions, laser beams, shadowgraphs, and tricky lighting effects (among them Richard Foreman's familiar habit of focusing blinding lights in the audience's eyes) (Brustein).

Yet there is hope for a more successful exploitation of the play's potential, learning from the first essay by the RSC.

\section{WORKS CITED}

Brustein, Robert (2003). 'Why Plays Fail', The New Republic, 14 April.

GiBBONS, FIACHRA (2002). "RSC to put Rushdie's jinxed saga on stage”, The Guardian, 22 October.

"InTERVIEW WITH Salman Rushdie", (2003). Time Magazine, reprinted in The Sunday Leader, 26 January.

JAMES, CARYN (2003). "Critic's Notebook; After the Fatwa, Playwriting and Partygoing", The New York Times, 9 March.

Rushdie, Salman, Simon Reade And Tim Supple (2003). Salman Rushdie's Midnight's Children, New York: Modern Library. 